\title{
リモートセンシング輝度温度による都市域気温分布の推定 \\ 一北部九州、関西、関東3地域への適用と比較一 \\ ESTIMATION OF THE TEMPERATURE DISTRIBUTION IN URBAN AREAS BY USING REMOTE SENSING DATA
}

金子慎治* 前田利家** 上野賢仁*** 井村秀文*

Shinji KANEKO*, Toshiie MAEDA**, Takahito UENO***, Hidefumi IMURA*

（全文審查の上、受理。1994年 7 月25日）

\begin{abstract}
The objective of this study is to develop practical methods of translating brightness temperature data obtained from satelites such as LANDSAT and NOAA into air temperature. There are two typical cases where the methods sould be applied. In the first case, reference temperature data observed at a sufficient number of points are available, e.g., from AMeDAS (Automated Meteorological Data Acquisition System), and the brightness temperature data obtained from LANDSAT TM and NOAA can be compared with these data. Then spatial distribution pattern of air temperature can be produced by using the correlation formula obtained by regression analysis. This study examines the method for three areas, i.e., the Kanto, Kansai (each area size being $80 \mathrm{~km} \times 80 \mathrm{~km}$ ) and North-Kyushu (area size being $40 \mathrm{~km} \mathrm{x} 40 \mathrm{~km}$ ) areas. In the second case, no reference temperature data are available, and another method is developed by using the one-dimensional energy budget model. Here, air temperature is estimated by assuming that the brightness temperature represents the surface temperature. The applicability of this method is tested for the Kanto region.
\end{abstract}

KEYWORDS; urban heat island, air temperature distribution, brightness temperature, LANDSAT TM, NOAA, AMeDAS

\section{1.はじめに}

都市化による地表面被覆の改変や人工排熱の增加にともなう環境変化としてヒートアイランド等の局地 的な気候が注目されている。こうした都市特有の気候の特性を分析・評価するためには、都市の気温分布 を面的に把握・評価することがまず必要となる。しかし、実際には、観測点の数や頻度などに限界があり、 気温の面的分布を作成するに足る数の観測点で気温分布を得るには多大な労力と時間を要する。これに対 して、衛星デー夕を利用すれば、広範な地域にわたる面的な温度（辉度温度）の情報を得ることができる。 この輝度温度と気温との間に一定の関係を見いだすか、あるいは、輝度温度から気温を導き出す方法が開 発されれば、都市の熱構造に関してもっと細密なデー夕提供が可能になる。

本研究では北部九州（福岡市周辺）、関西、関東の3地域を解析対象とし、リモートセンシングデータと AMeDAS観測データを用いた以下の解析を行う。(1)AMeDAS観測点の気温と輝度温度の関係を求め、回帰 式により3地域、朝夕の気温分布を推定する。(2)各地域それぞれの気温分布図を作成し、相互の特性を比 較・考察する。特に、関東地域に着目し、気温分布と地表面被覆の関係を分析する。(3)一次元熱収支モデ ルを用いて輝度温度から気温を推計し、AMeDAS観測気温との一致検証する。これによって、輝度温度か

*九州大学工学部環境システム工学研究センター Institute of Environmental Systems, Faculty of Engineering, Kyushu University $* *$ 福岡市 Fukuoka City

***熊本工業大学土木工学科 Department of Civil Engineering, Kumamoto Institute of Technology 
ら気温分布を推計する1つの実際的な方法

表 1 解析に用いたデー夕

を呈示する。

\section{2. 解析手法}

解析に使用するデー夕を表 1 にまとめ る。また、僻析の地理的範朋とAMeDAS微

\begin{tabular}{|c|c|c|c|}
\hline 衛星 & 撮影日 & 撮影時刻 & 解析対象地域 \\
\hline \multirow[t]{3}{*}{ LANDSAT TM } & 1988年4月15日 & 午前 10 時 00 分 & 北部九州 \\
\hline & 1992年4月21日 & 午寉10時00分 & 関西 \\
\hline & 1993年4月19日 & 午前 10 時00分 & 関東 \\
\hline \multirow[t]{2}{*}{ NOAA } & 1993年4月19日 & 午前7時56分 & 北部九州、関西、関東 \\
\hline & 1993年:4月19! & 个後7㭙15分 & 北部九州、開西、閣東 \\
\hline
\end{tabular}
测点の分布を図 1 に示す。

まず、LANDSAT TMデー夕を経緯度法により幾何補正した後、バンド1〜5、7より被覆分類図を、バン ド6より輝度温度図を作成する。輝度温度は、 $120 \mathrm{~m} \times 120 \mathrm{~m}$ のメッシュデータを面積平均し、 $1 \mathrm{~km} \times 1 \mathrm{~km}$ メッシュデー夕とする。次に、NOAAデータについて幾何補正を行い、バンド4、5より大気補正を行った

輝度温度図を作成する。

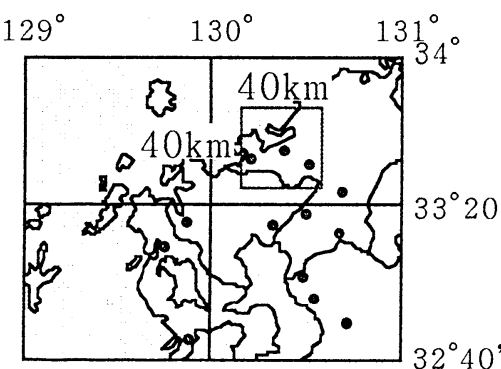

(a) 北部九州地域

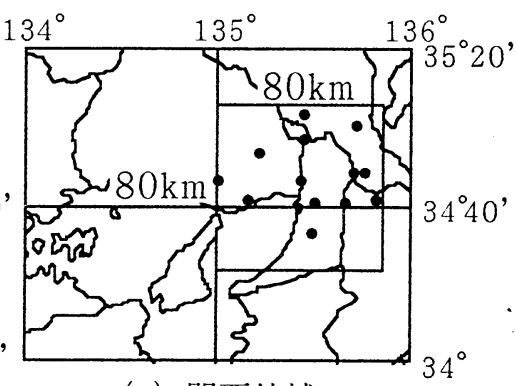

(b) 関西地域

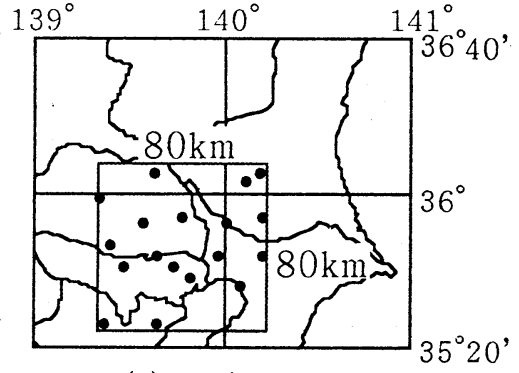

(c) 関東地域

図 1 解析対象範囲

3. 回帰式による気温分布の推定

\subsection{AMeDAS観測点の輝度温度と気温の関係}

AMeDAS観測点を含むメッシュ $(1 \mathrm{~km} \times 1 \mathrm{~km})$ の輝度温度とAMeDAS観測気温の相関を調べたのが図 2 で

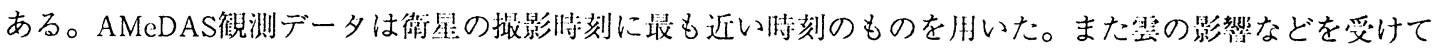

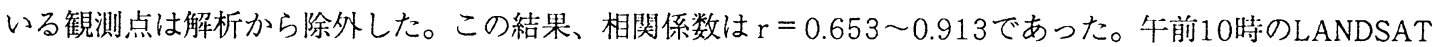

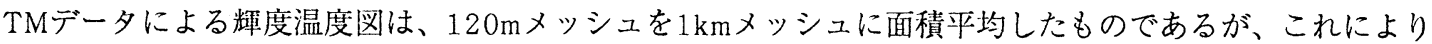
相関係数はかなり改善される。120mメッシュでの輝度温度の場合は河川や道路などで明瞭な不連続が現わ れるが、 $1 \mathrm{~km}$ メッュで平均化した輝度温度分布では、メッシュ内でのバラッキが抑えられたため気温との 相関が良くなったものと考えられる。

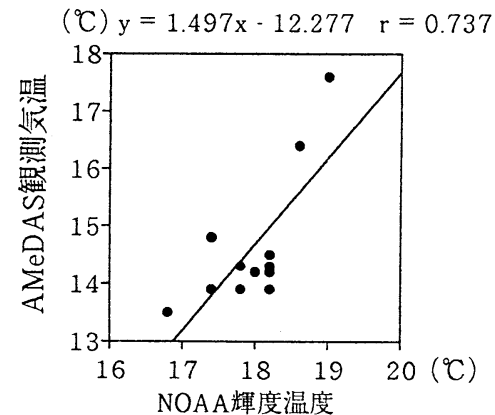

北部九州（1993年4月19日午前7時56分）
(C) $y=0.365 x+5.988 \quad r=0.831$

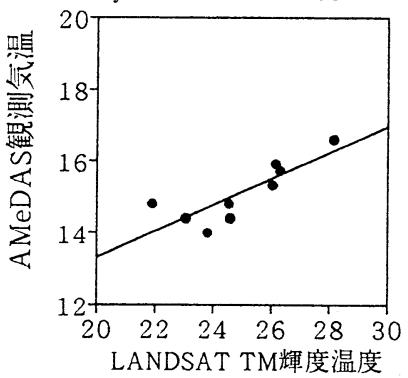

$\left({ }^{\circ} \mathrm{C}\right) \mathrm{y}=1.344 \mathrm{x} \cdot 5.675 \mathrm{r}=0.653$

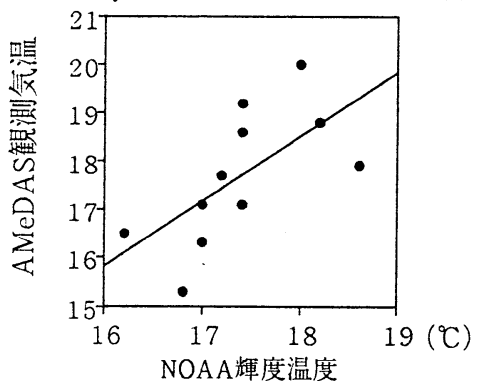

図 $2 A M e D A S$ 観測気温と輝度温度の関係 
$\left({ }^{\circ} \mathrm{C}\right) \mathrm{y}=1.571 \mathrm{x}-13.977 \mathrm{r}=0.913$

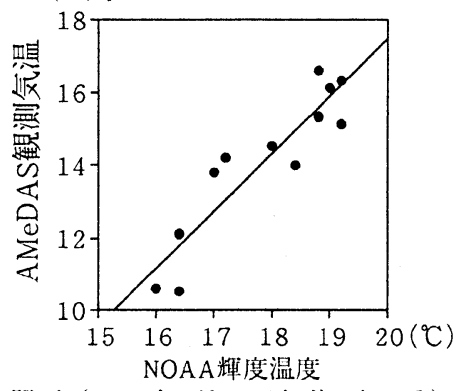

関选（1993年4月19日午前7時56分）

$\left({ }^{\circ} \mathrm{C}\right)_{\mathrm{y}}=1.777 \mathrm{x}-17.178 \mathrm{r}=0.839$

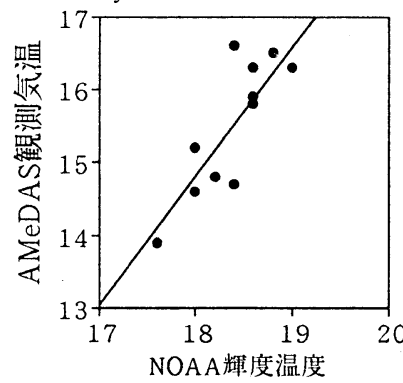

间東（1993年4月19日年前7時56分）

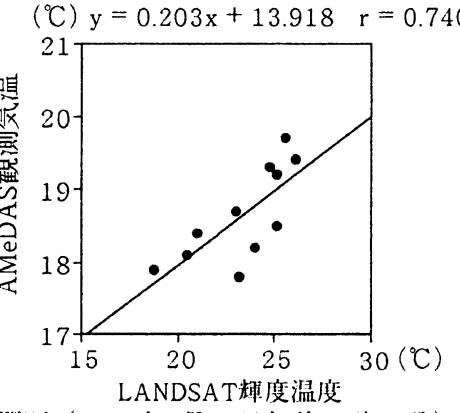

関陌（1992年4月18日午㭥10時00分）

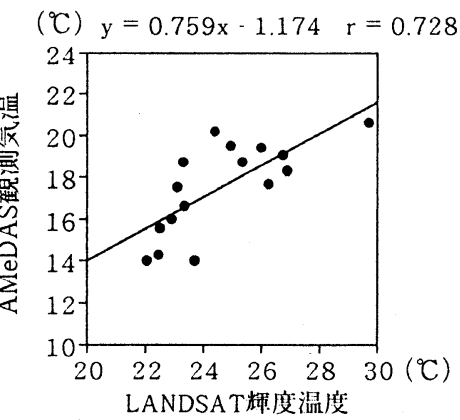

阙束（1993作4月19日午前1015:00分）

図 $2 A M e D A S$ 観測気温と輝度温度の関係 $\left({ }^{\circ} \mathrm{C}\right) \mathrm{y}=0.854 \mathrm{x}+3.649 \mathrm{r}=0.793$

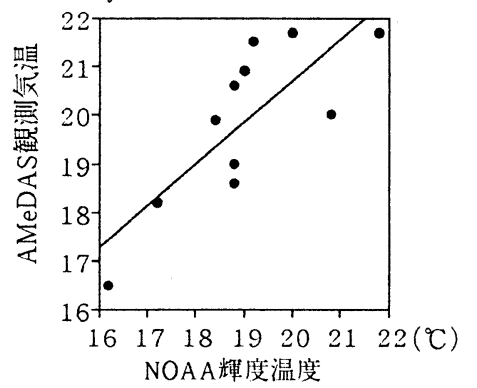

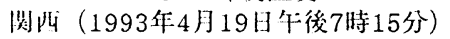

$\left({ }^{\circ} \mathrm{C}\right) \mathrm{y}=0.432 \mathrm{x}+5.121 \mathrm{r}=0.891$

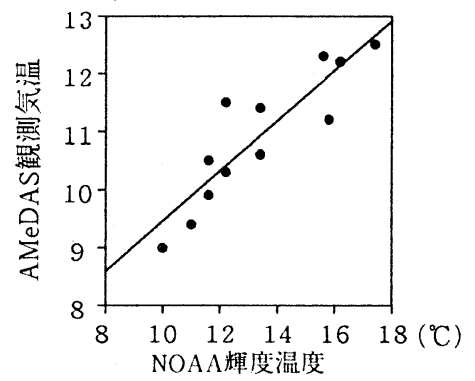

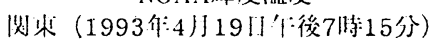

\subsection{3 地域、朝夕の気温分布}

3.1 で求めたそれぞれの回帰式を用い、北部九州（福岡市周边、 $40 \mathrm{~km} \times 40 \mathrm{~km}$ ）、関西 $(80 \mathrm{~km} \times$ $80 \mathrm{~km})$ 、関東 $(80 \mathrm{~km} \times 80 \mathrm{~km})$ の3地域について、午前 8 時 $(\mathrm{NOAA})$ 、午前10時（LANDSAT）、午後7 時（NOAA）の3時刻の気温分布図を作成した。これを図 3、4、5に示す。ただし、北部九州及び関西地 域の午前10時（LANDSAT）のデータについては、データ入手上の問題から、午前8時及び午後7時のデー 夕とは、日が若干淇なっている。

関西と北部九州諸都市のいずれの時刻についても都市の中心付近で最高気温が確認できる。福岡市周辺 では三郡山地、脊振山地、大阪市周辺では六甲山地、金剛生駒山地、和泉山脈等が都市部を囲んでおり、 このことが都市規模のかなり違う両地域のヒートアイランドの分布形状の類似に影響を及ほしていると考 えられる。また、朝の気温分布について、都市部と郊外の温度差が比較的小さいことが分かる。

これに対し関東地域では、気温分布の様子が時間的に変化する。日中は高温域が都心部ではなく埼玉県 南東部付近で見られるのに対し、午後7時頃では都心部の気温が高いことが分かる。同様の傾向はAMeDAS 観測気温の日変化にも見られる。ここで、北部九州及び関西地域に比べて午後7時の気温が低いのは、日没

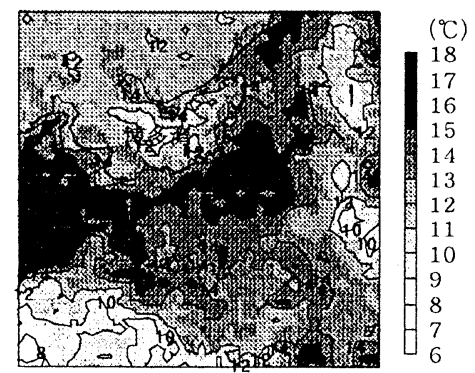

(a) 1993年4月19日午前8時

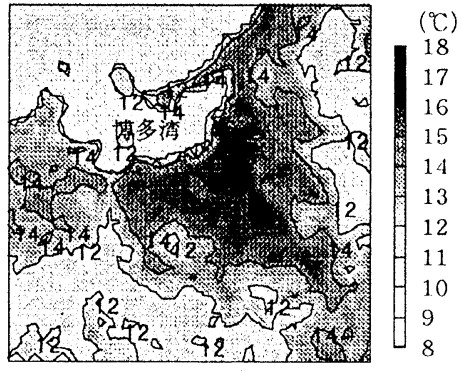

（b） 1988 年4月 15 日午前 10 時

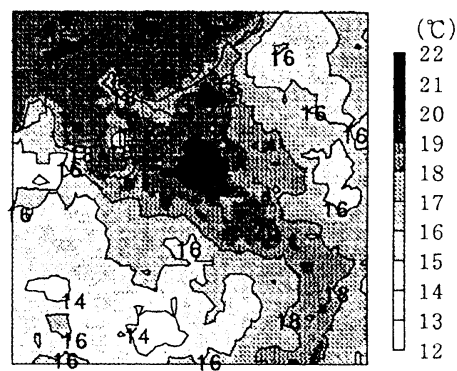

(c) 1993 年 4 月 19 日午後7時

図 3 福岡市周辺、朝夕の気温分布図 


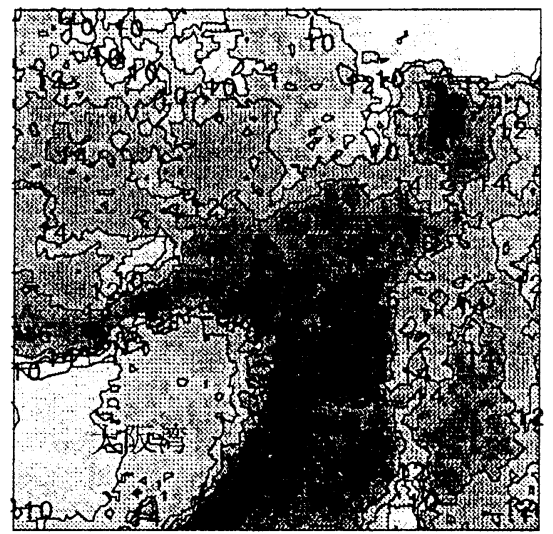

(a) 1993年4月19日午前8時

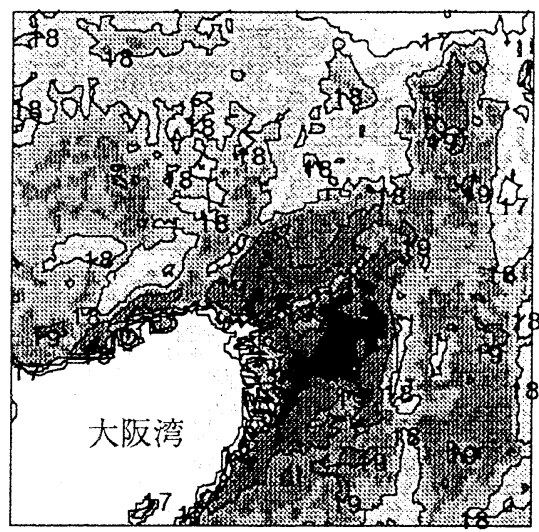

（b） 1992年4月18日午前10時

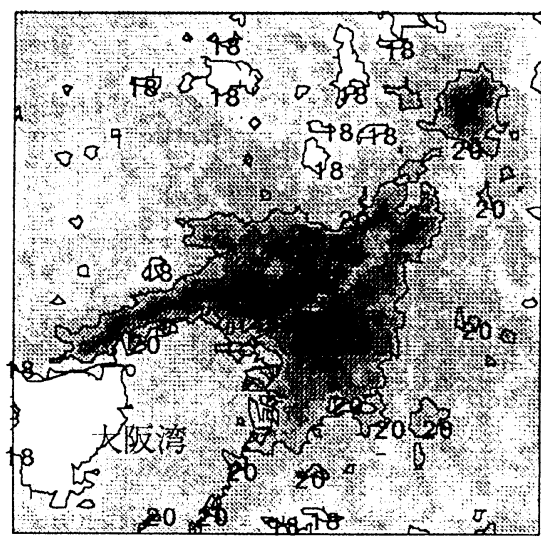

(c) 1993年4月19日午後7時

図4関西地域、朝夕の気温分布図

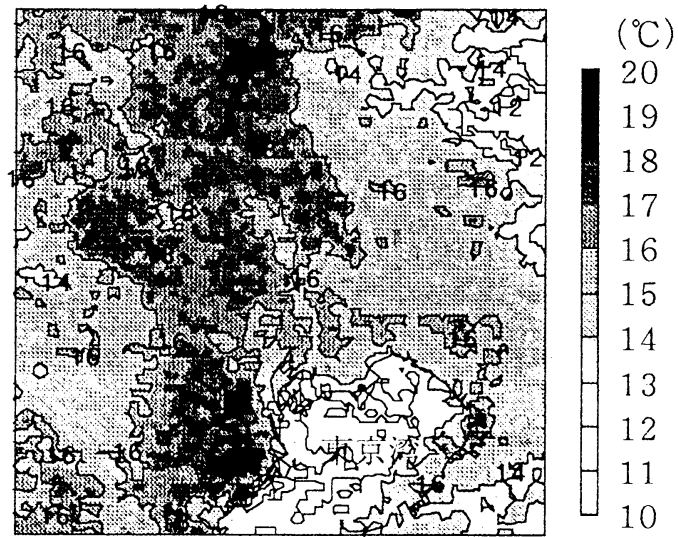

(a) 1993年4月19日午前8時
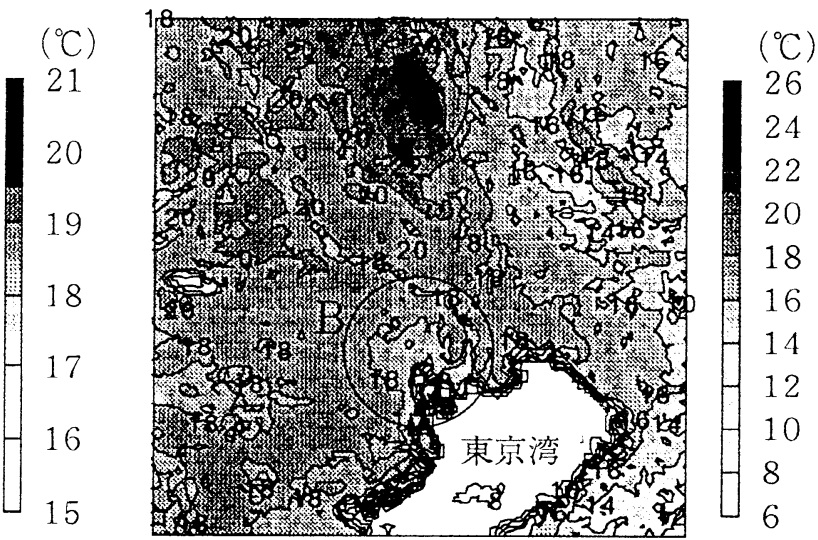

（b）1993年4月19日午前10時

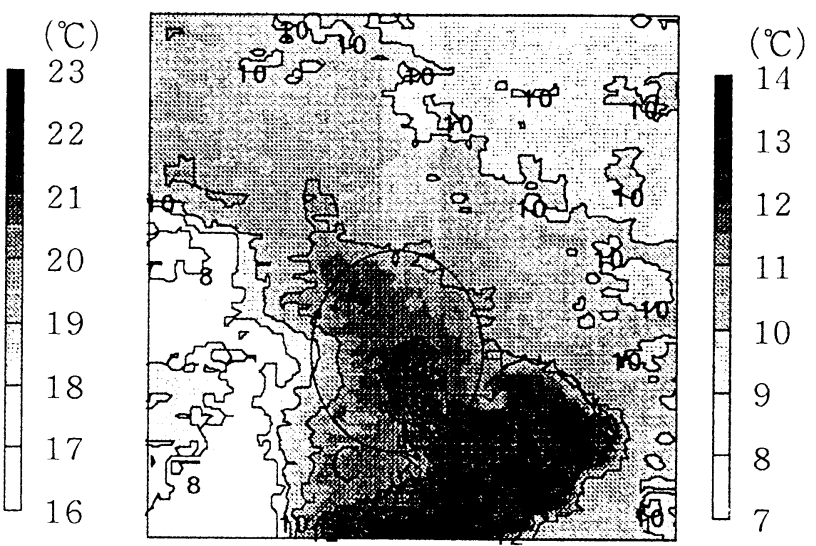

(c) 1993年4月19日午後7時

図 5 関東地域、朝夕の気温分布図 
が早いことと、解析範国の左下の部分に見られる雲の影響が考えられる。関東地域の気温分布が他の 2 地域 と異なっている理由としては、関東平野が広範囲であることや、風の挙動や地表面の被覆状態などの影響 が考えられる。

\section{3 関東地域の気温分布と被覆状態の関係}

関東地域は、関西地域や福岡市周辺地域と異なった父温分布がみられた。そこで栭東地域において買な る時刻の父温答と被稪状帒の网係を洞べた。

3.2 でみた関東地域の午前10時及び午後7時の気温差と被蕧状態の関係を見たのが図6である。ここでは 雲のかかった部分と海域を除いたデー夕 (4728個) を用いている。LANDSAT TMデー夕より求めた被覆 分類図をもとに、各归を゙リーの被覆状態であると判別された最小メッシュ（30mメッシュ）が、1 kmメッ シュ内に上める割合を求め、これを被覆率とした。このような定義により、裸地率（裸地及び畑の制合）、 緑地率及びコンクリート等の被覆率を求めた。ここで、コンクリート等には、人工材料であるコンクリー ト、アスファルト、スチール、高層ビル、住宅地を含めることとした。

図 6 (a)より、裸地率と気温差には一定の傾问がみられることがわかる。一般に、裸地率が高くなると日 中と夜間の気温差が大きくなる。裸地の多い場所では、日中は地表面温度が上昇しやすく、逆に夜間は地 表面温度が下がりやすい。周辺の気温も同様の倾问を示しているものと考えられる。また、図 6(b)では、 緑地率が3割を越えると気温差との関係が顕著となり、相関係数は $\mathrm{r}=0.400$ となる。緑地率が大きくな

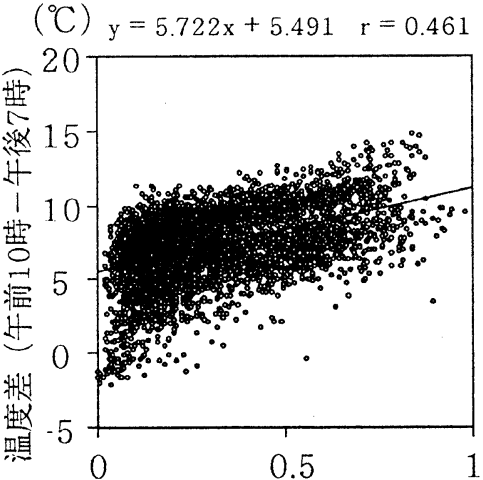

(a) 裸地率

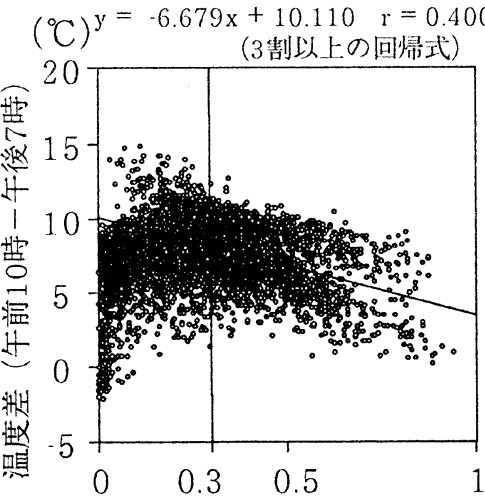

(b) 緑地率 $\left({ }^{\circ} \mathrm{C}\right) \mathrm{y}=-0.474 \mathrm{x}+7.423 \quad \mathrm{r}=0.053$

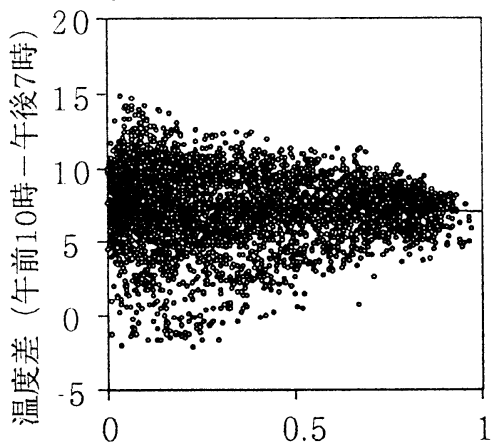

(c) コンクリート等の被覆率

図 6 被覆と輝度温度の差との関係

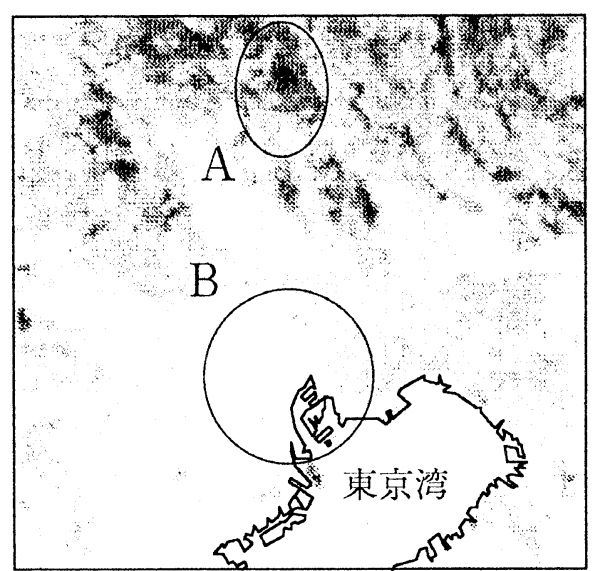

(a) 裸地率の分布

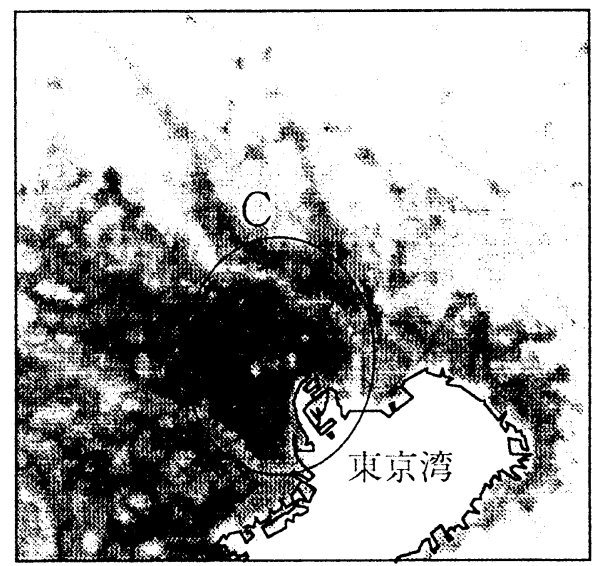

(b) コンクリート等の被覆率の分布

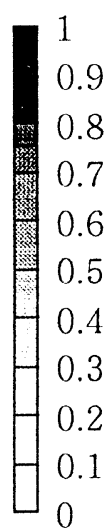

0.9

0.8

0.7

0.6

0.5

0.4

0.3

0.2

図 7 関東地域の被覆率の分布 
ると温度差は小さくなり、緑地は気温上昇を抑制する効果を持つといえる。

図 6 (a)、(c)より、都市部における気温の高低差は、裸地率の高い場所に比べて小さいといえる。このよ うな特徵が広範な地域全体にわたり確珰できる理由として、関東地域では平野部が広く、裸地と判別され る地表面の割合が比較的多いことが挙げられる。そこでは督夜の気温変動が地表面温度と連動して顕著に 起こり、北部九州及び関西地域の気温分布との相違を引き起こしていると考えられる。図 7 は裸地率と人

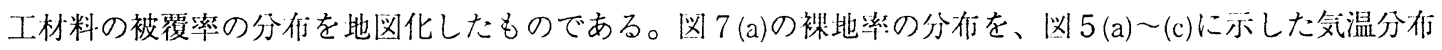

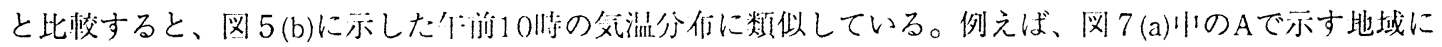
おいて裸地率が高いが、気温についても図 $5(\mathrm{~b})$ ゆのAで示す地域で淌くなっている。この時の最高気温もこ の地域で確認できる。また、図 7 (a)中のBで示す地域において裸地率は低くなっているが、気温についても

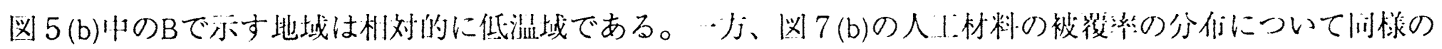
比較を行うと、図 5 (c)に示した午後7時の気温分布に類似している。図 7 (b) 万び図 5 (c)中のそれぞれCで示 した地域をみると、共に高い值が分布している。以上のような、昼夜の気温差と被覆率の関係及び被覆率 と気温の面的な広がりの比較により、関東地域での気温分布を特徵づける決定的な要因の1つとして、地 表面の被覆状態の違いが挙げられる。

\section{4. 一次元熱収支モデルによる気温の推定}

上では、輝度温度とAMeDAS觀测気温の関 係を求め、一定の精度で、簡健に気温分布が 得られることを示した。また、実際にこれを 用いて3地域における気温の平面的分布特性 を比較・考察した。しかし、地表面状態が及 ぼす影響等を考えれば、本来的に、輝度温度 と気温との関係は単純な直線式で関係づけら

\begin{tabular}{|c|c|c|c|c|c|c|}
\hline \multicolumn{2}{|r|}{ 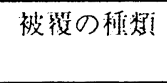 } & $\begin{array}{c}\text { アルベド } \\
-\end{array}$ & $\begin{array}{l}\text { 䓡拡敬係数 } \\
\mathrm{cm}^{2} \mathrm{~min}^{-1}\end{array}$ & $\begin{array}{c}\text { 熟容胃 } \\
\text { cal } \mathrm{K}^{1} \mathrm{~cm}^{3} \\
\end{array}$ & $\begin{array}{c}\text { 粗度长 } \\
\mathrm{m}\end{array}$ & $\begin{array}{c}\text { 蒸発能 } \\
-\end{array}$ \\
\hline \multicolumn{2}{|c|}{1 高層ビル群 } & 0.28 & 0.45 & 0.56 & 300 & 0 \\
\hline \multirow{2}{*}{$\begin{array}{l}2 \\
3\end{array}$} & 住宅地 & 0.25 & 0.19 & 0.4 & 100 & 0.1 \\
\hline & 森林 & 0.15 & 0.14 & 0.36 & 100 & 0.7 \\
\hline 4 & 草地 & 0.1 & 0.13 & 0.38 & 30 & 0.3 \\
\hline 5 & 裸地 & 0.2 & 0.1 & 0.3 & 0.1 & 0.3 \\
\hline
\end{tabular}
れる性質のものではない。また、ある地域のある镜測日に おいて得られた関係式は、その特定の条件下でのみ成立す るものでしかない。跕度温度を所与として気温を推計する 解析的なアルゴリズムの開発が求められる。

地表面温度から気温を推計する方法として、近藤1は、 熱收支式を解析的に解く方法を示している。しかし、その

表 3 境界条件

計算のためには地点 (メッシュ) ごとに諸パラメータの值を決定する必要があり、広域にわたってこの方 法を実行するのは容伯ではない。そこで、比較的簡単に実 行できる1つの簡便な方法として、ここでは、輝度温度を 地表面温度と見なし、Atwaterの一次元熱収支モデル2)、31 を応用することによって気温を推計することを試みる。な お、依田ら ${ }^{4)}$ は、同様の熱バンド変撸による輝度温度と地 表面温度の関係について、雨者がよく一致することを見い だしている。

熱收支モデルの典型的な計算においては、境界条作（大 父上空の温度・風速及び地中温度）を所与とした上で、地 表面状態を表すパラメー夕を地点ごとに与え、計算を実行 して地表面温度と気温を求める。もし、この計算によって 得られる地表面温度を、観测された地表面温度（ここで は、輝度温度をそれとみなす）に一致させることが出来れ

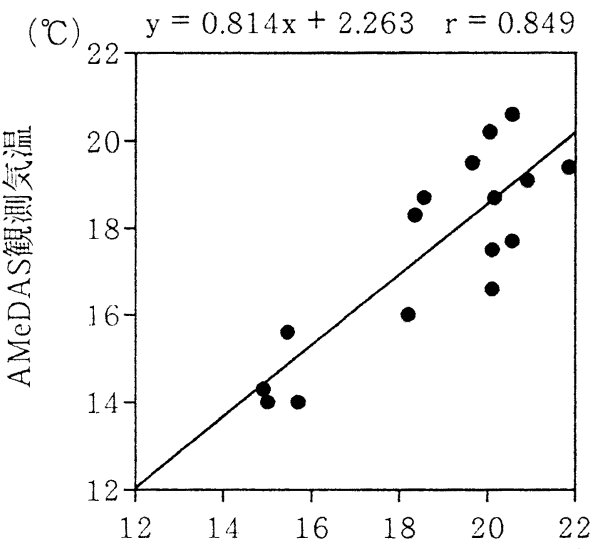

$\left({ }^{\circ} \mathrm{C}\right)$

図 8 計算結果とAMeDAS観測気温の関係 
ば、このモデルによって気温を推計することが叮能と言える。しかし、単純な一次元熱収支モデルでは、 風場の影響が全く考虑されない上に、調節问能なパラメー夕の数も少ないので、現寒の温度分布を再現す るのは非常に難しい。実際には、上空・地中の境界条件と地表面パラメータだけを与えて一次元熱収支モ デルで計算すると、地表面、気温とも実際の観测值よりもかなり大きめの結果となってしまう。その理由 としては、熱の移流を無視していることが大きい。そこで、一次元熱収支モデルによって計算される地表 面温度を観測值に一致させるようにするには、系外に熱を排除させるような人為的な計算操作が必要であ る。そのための具体的な方法として、ここでは、境界条件として与える地中の温度を現実よりも低く設定 することにし、仮想的に熱が地中に排除されるようにした。これは、あくまでも、モデル計算によって得 られる地表面温度を観测值に一致させるための人為的操作である。

以下の具体的な計算においては、まず、上に述べたような操作によって地表面温度を観測值に一致させ

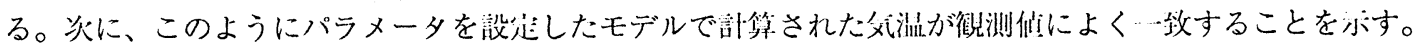

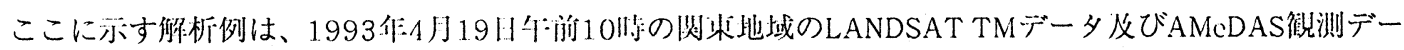
夕を用いたものである。まず、LANDSAT TMデータから作成した被覆分類四をもとに、AMeDAS観測点を 含むメッシュ $(1 \mathrm{~km} \times 1 \mathrm{~km})$ について、被栭カテゴリーの割合を求めた。これと地図等を参考にして、各 メッシュを代表的な 5 種の地表面状態に分類し、表 2 に示すように地表面パラメータを設定した。また、 計算に用いた大気上空境界条件を表 3 に示す。地点（メッシュ）ごとに、計算温度が観測值（輝度温度） と一致するように地中温度は現実よりかなり低く設定したが、その場合の地表面から地中への熱フラック ス量 $\Gamma は 、 0.35 \sim 0.54 \mathrm{cal} / \mathrm{cm}^{2} \cdot \min$ である。この值は、現実の值より相当に大きめである。このような操 作を加えることによって、一次元熱収支モデルによって計算される地表温度を钼測值に一致させ、高度 $1.5 \mathrm{~m}$ の気温を計算した。こうして求めた計算温度とAMeDAS観測気温（観測値）との関係を示したのが図 8 で ある（相関係数は $\mathrm{r}=0.849 ） 。$

ここで示した方法においては、地表面の計算值と観测值を一致させるために、人為的な計算操作（現実 とはずれたパラメー夕設定）を行わざるを得なかった。これは、一次元熱収支モデルを用いることの限界 である。しかし、輝度温度から気温を推計する 1 つの実際的な方法として、一定の有効性を持つものであ る。

\section{5. 結論}

本研究で得られた結論を以下にまとめる。

1） $\mathrm{AMeDAS}$ 観測点の気温と輝度温度の関係を求め、得られた回帰式を用いて、輝度温度分布図から 3 地 域、朝夕の気温分布図を求めた。

2）1）で求めた気温分布図を用いて、3地域の気温分布について、検討した。関東地域での気温分布は福岡 市周辺や関西地域と異なっており、地表面の被覆状態が主要な原因の一つであることが示された。

3）一次元熱収支モデルにおいて、計算地表面温度が輝度温度に一致するようにパラメー夕を調節し、これ によって推計された気温がAMeDAS観測気温によく一致することを検証した。

今後は、それぞれの被覆状態に対応した適切かつ簡便な地表面パラメータの設定方法を確立すること、 輝度温度より、地表面温度を所与として気温を求めるモデルの開発・改善を図ることが課題である。

\section{《参考文献》}

1) 近藤純正：農業気象、Vol. 48 (3)、pp. 265 275、1992.

2) Atwater, M. A. : Boundary - Layer Meteorology , Vol. 3, pp. 229 245, 1972.

3）上野賢仁ら：環境システム研究、Vol.20、pp. 262〜269、1991.

4）低田浩敏ら：日本リモートセンシング学会、第12回学術講演会論文集、pp. 19〜22、1992. 